Review

\title{
Tectono-Sedimentary Evolution of the Cenozoic Basins in the Eastern External Betic Zone (SE Spain)
}

\author{
Manuel Martín-Martín ${ }^{1, *(1)}$, Francesco Guerrera ${ }^{2}\left[\right.$ and Mario Tramontana ${ }^{3}(1)$ \\ 1 Departamento de Ciencias de la Tierra y Medio Ambiente, University of Alicante, 03080 Alicante, Spain \\ 2 Formerly belonged to the Dipartimento di Scienze della Terra, della Vita e dell'Ambiente (DiSTeVA), \\ Università degli Studi di Urbino Carlo Bo, 61029 Urbino, Italy; francesco@guerrera.biz \\ 3 Dipartimento di Scienze Pure e Applicate (DiSPeA), Università degli Studi di Urbino Carlo Bo, \\ 61029 Urbino, Italy; mario.tramontana@uniurb.it \\ * Correspondence: manuel.martin.m3@gmail.com
}

Received: 14 September 2020; Accepted: 28 September 2020; Published: 3 October 2020

\begin{abstract}
Four main unconformities (1-4) were recognized in the sedimentary record of the Cenozoic basins of the eastern External Betic Zone (SE, Spain). They are located at different stratigraphic levels, as follows: (1) Cretaceous-Paleogene boundary, even if this unconformity was also recorded at the early Paleocene (Murcia sector) and early Eocene (Alicante sector), (2) Eocene-Oligocene boundary, quite synchronous, in the whole considered area, (3) early Burdigalian, quite synchronous (recognized in the Murcia sector) and (4) Middle Tortonian (recognized in Murcia and Alicante sectors). These unconformities correspond to stratigraphic gaps of different temporal extensions and with different controls (tectonic or eustatic), which allowed recognizing minor sedimentary cycles in the Paleocene-Miocene time span. The Cenozoic marine sedimentation started over the oldest unconformity (i.e., the principal one), above the Mesozoic marine deposits. Paleocene-Eocene sedimentation shows numerous tectofacies (such as: turbidites, slumps, olistostromes, mega-olistostromes and pillow-beds) interpreted as related to an early, blind and deep-seated tectonic activity, acting in the more internal subdomains of the External Betic Zone as a result of the geodynamic processes related to the evolution of the westernmost branch of the Tethys. The second unconformity resulted from an Oligocene to Aquitanian sedimentary evolution in the Murcia Sector from marine realms to continental environments. This last time interval is characterized as the previous one by a gentle tectonic activity. On the other hand, the Miocene sedimentation was totally controlled by the development of superficial thrusts and/or strike-slip faults zones, both related to the regional geodynamic evolutionary framework linked to the Mediterranean opening. These strike-slip faults zones created subsidence areas (pull-apart basin-type) and affected the sedimentation lying above the third unconformity. By contrast, the subsidence areas were bounded by structural highs affected by thrusts and folds. After the third unconformity, the Burdigalian-Serravallian sedimentation occurred mainly in shallow- to deep-water marine environments (Tap Fm). During the Late Miocene, after the fourth unconformity, the activation of the strike-slip faults zones caused a shallow marine environment sedimentation in the Murcia sector and a continental (lacustrine and fluvial) deposition in the Alicante sector represented the latter, resulting in alluvial fan deposits. Furthermore, the location of these fans changed over time according to the activation of faults responsible for the tectonic rising of Triassic salt deposits, which fed the fan themselves.
\end{abstract}

Keywords: eastern External Betic Zone; Cenozoic basins; strike-slip tectonics; tectono-sedimentary evolution 


\section{Introduction}

The study area is located in the Murcia and Alicante provinces of the SE Spain (Figure 1A), which belong to the eastern External Betic Zone (EBZ). This cordillera is included in the Alpine chains of the western Mediterranean (Figure 1B), resulting from the continental collision of the Mesomediterranean Microplate (MM) (Guerrera et al. [1]) at first with the Iberia-Europe Plate (Cretaceous-Paleogene: Eo-Alpine phase), and subsequently, (Miocene: Neo-Alpine or Maghrebian phase) with the Africa Plate and due to the ocean closures driven by oppositely oriented subductions [1-6]. These processes affected the western branches of the Tethys (Figure 1C), generating Mesozoic to Tertiary successions related to several tectono-sedimentary domains [7]. The development of a rifting affecting the South Iberian Margin generated basins with alpine-like platforms (extended and wide, and structured in horsts and grabens), characterized by marine domains which are deeper from north to south, forming the Prebetic (to the north) and the Subbetic (to the south) of the EBZ [7-9].

The deposition in the Cenozoic basins followed the tectonic inversion (from extension to compression) occurring at the latest Cretaceous, being usually marked by a generalized unconformity [10]. Sometimes, Paleogenic deposits show paleoenvironmental conditions similar to those of the Mesozoic successions, and sedimentation is a continuation of the former. In these cases, shallow water sediments deposited above the inherited structural highs (horsts), passing laterally to deep realms (grabens). In particular, the deep deposits are characterized by turbidite deposits with olisthostrome and slumps on the slope and more deep areas [11-15].

Vera $[16,17]$ provided a general framework of the Mesozoic to Cenozoic sedimentation of the EBZ, dividing the stratigraphic record into eight main sedimentary cycles. Recently, detailed multidisciplinary studies carried out in the eastern EBZ suggested the following remarks about the tectono-sedimentary evolution of the area: (1) the definition of a new and earlier Paleogene deformation stage $[15,18,19]$, (2) the Paleogene deformation was related to the Internal Betic Zone (IBZ) tectonics paleo-geographically close to the IBZ, as proposed by Guerrera et al. [15], Guerrera and Martín-Martín [18] and Guerrera et al. [19], (3) the importance of strike-slip Miocene fault systems [20,21] and (4) the influence of salt tectonics also during the Miocene evolution [22-24]. Therefore, the knowledge of these Cenozoic basins has been considerably improved because these papers show their tectono-sedimentary evolution.

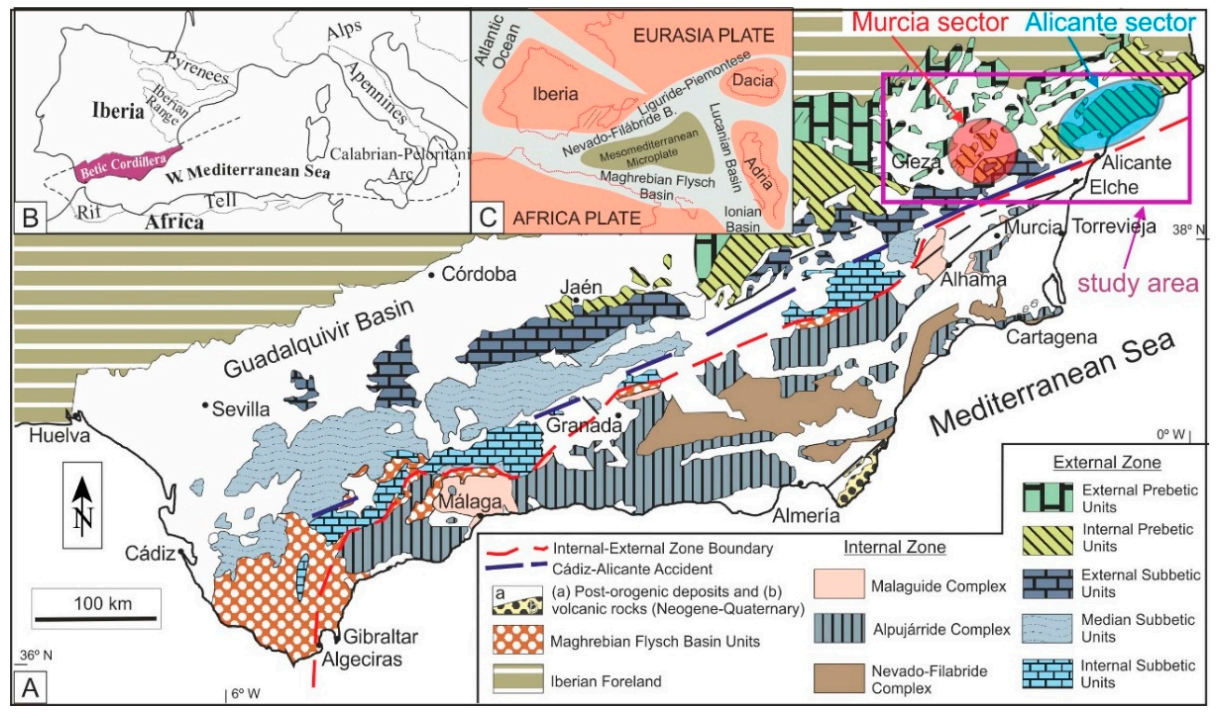

Figure 1. The Betic Cordillera (after Reference [19]; modified). (A) Geological map of the Betic Cordillera with the location of Cenozoic Basins of the eastern External Betic Zone (EBZ) (study area), the Murcia (Figure 2) and Alicante (Figure 3) sectors. (B) Geographic location of the Betic Cordillera in the context of the western Mediterranean alpine chains. (C) Paleogeographic sketch of the western Mediterranean area during the Cretaceous. 


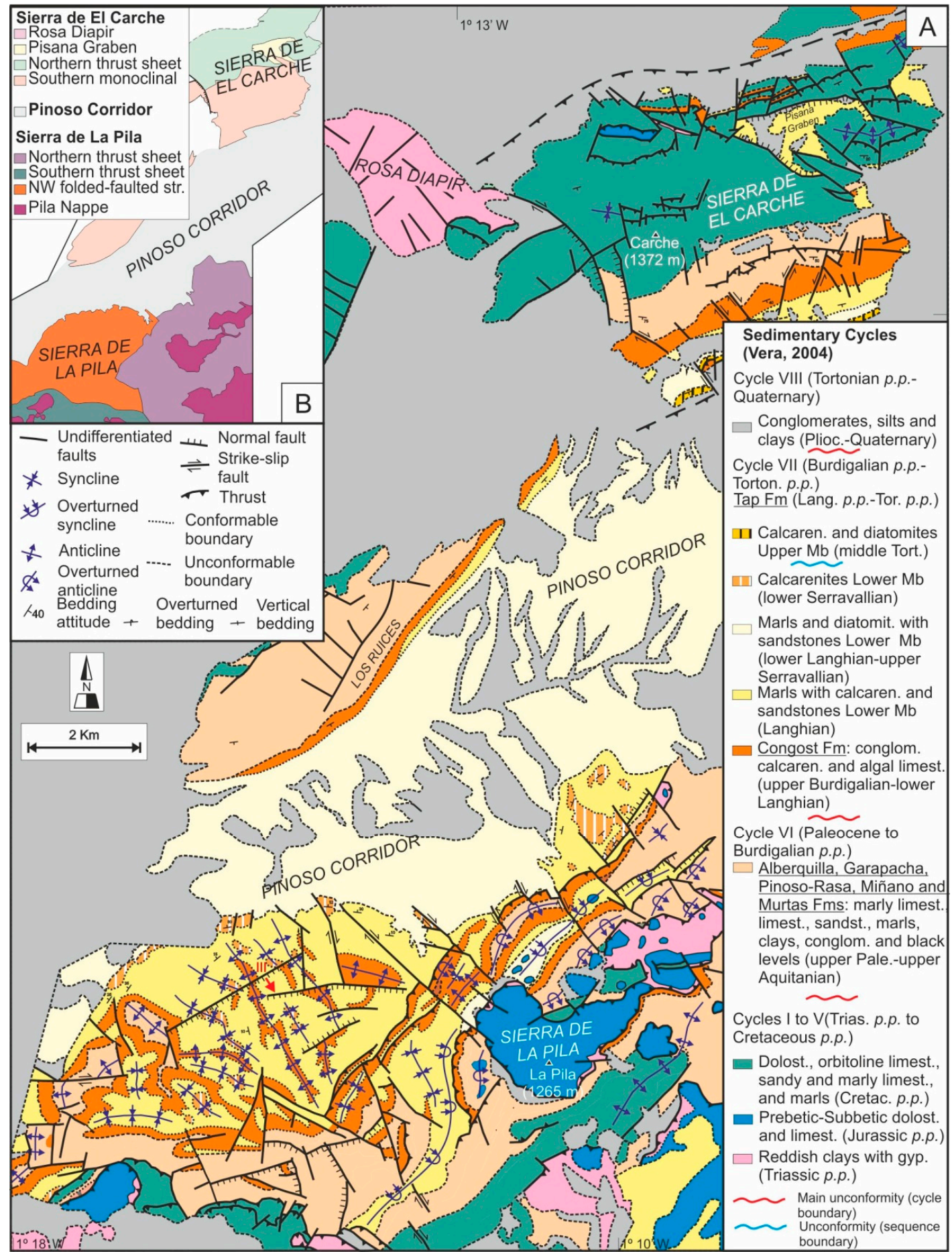

Figure 2. Geological maps of the eastern EBZ in the Murcia sector (after Reference [20]; modified). (A) Detailed geological map of the Pila-Carche area. (B) Structural sketch map of the Pila-Carche area. 


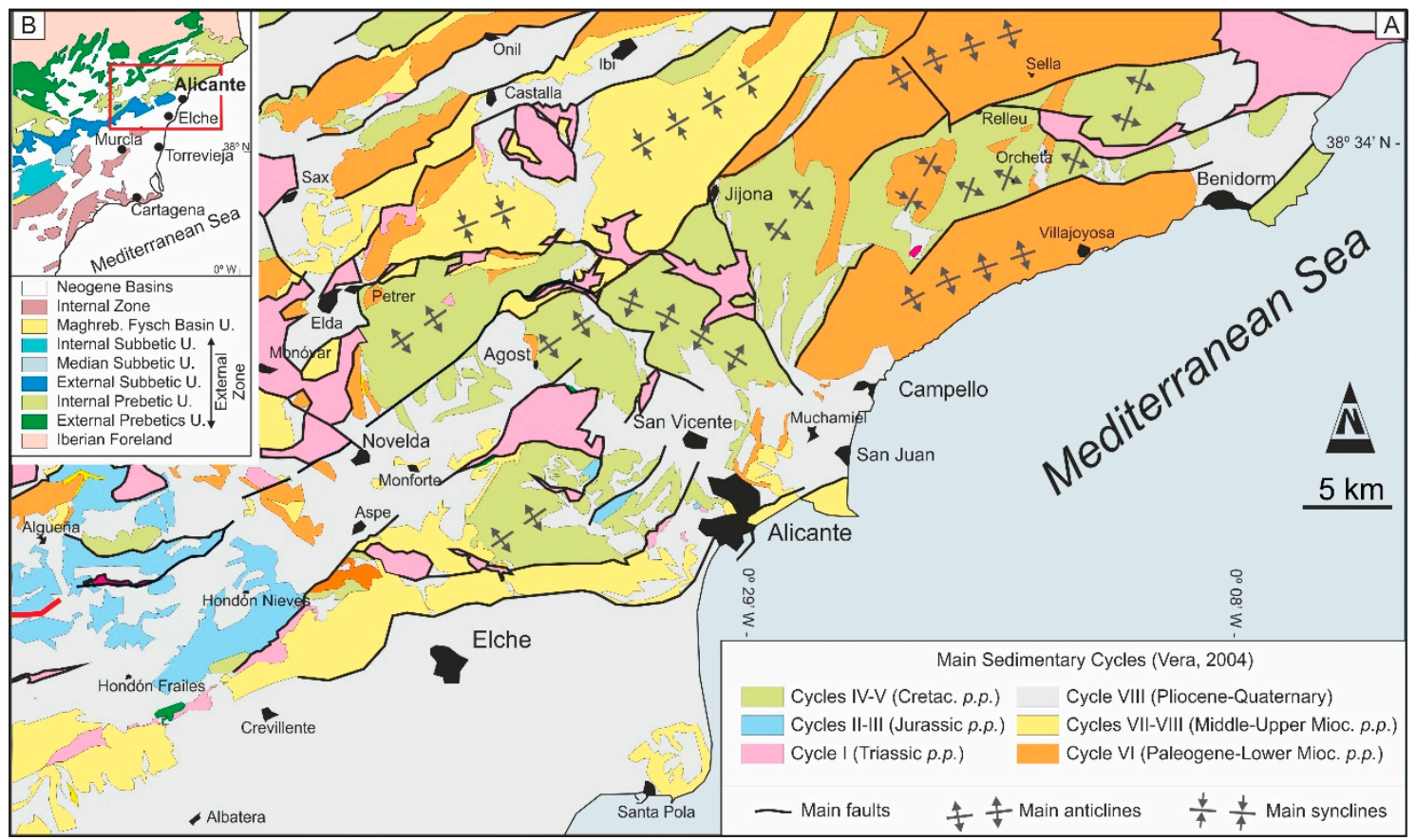

Figure 3. Geological maps of the eastern EBZ in the Alicante sector (after Reference [21]; modified). (A) Detailed geological map of the Alicante sector. (B) Structural sketch map of the Alicante sector.

In short, the main aim of this paper is to present a review of the evolution of the Cenozoic basins in the eastern EBZ, considering previous reconstructions and the broad recent literature. In concrete, the considered area corresponds to the Pila-Carche sector (Figure 2) and the Alicante sector (Figure 3) in the Murcia and Alicante provinces, respectively. The review also aims to propose the considered studied sector as a key area for studies addressed to the tectono-sedimentary evolution of Cenozoic basins in the western Mediterranean chains

\section{Background History}

The regional geological studies in the eastern Betics started at the end of the XIX century (e.g., the authors of References [25-29] pointed out that this area belonged to the Prebetic-Subbetic transition of the eastern EBZ). Several geomorphological alignments (mountains), bounded by Cenozoic basins, were signaled. These reliefs correspond with tectonic elements related to north-vergent fold-thrust nappes, as indicated by Rodríguez-Estrella [30,31]. Other authors [32-39] have also indicated that the area was affected by several Miocene-Quaternary strike-slip fault systems. The previous authors have also pointed the occurrence of salt tectonics processes associated to the strike-slip faulting.

According to previous works [29-31], during the Jurassic, the Prebetic (external-most domain) constituted a distal shallow carbonate platform, while the Subbetic (internal-most domain) was represented by a subsiding area, with deposition of deep-water pelagic marls. Later, during the Cretaceous, deep realms were widespread both in Prebetic and Subbetic domains. The Cenozoic shows a greater variety of sediments, which are marked by detritic supplies alternating with deep- or shallow-water deposits [16,29,40]. Many Neogene deformation phases were proposed [33]: thrusting (Early Miocene), normal faulting (Middle Miocene) and development of strike-slip faulting (Late Miocene). Furthermore, studies concerning the Eocene platform areas were carried out by Geel $[12,13]$ and Geel et al. [14]. Also, analyses on deeper marine sediments were developed by Roep and Everts [11].

More recently, specific papers concerning the tectono-sedimentary evolution of Cenozoic basins in the eastern EBZ have been published. Guerrera et al. [15] and Guerrera and Martín-Martín [18] propose the Paleogene evolution of the Cenozoic Alicante Trough Basin characterized by a narrow shaped sedimentary basin with tectonically active margins located to the NNW in the Jijona-Elda area 
(mainly functioning during the Eocene) and to the SSE in a position now under the Mediterranean sea (during the Oligocene), respectively. The infilling of the Alicante Trough, which is subdivided by two unconformities into two depositional sequences (Eocene p.p. and Oligocene p.p. in age, respectively), pointed out "catastrophic" syn-sedimentary tectonic processes including slumps, mega-olisthostromes, "pillow-beds" and turbidite deposits.

Analyzing the Paleogene evolution of the Pila and Carche basins (EBZ, north of the Murcia province), Guerrera et al. [19] recognized several depositional sequences (defined Middle-Upper Maastrichtian, Upper Paleocene-Middle Eocene, and Oligocene-Lower Aquitanian in age) with associated slumps and olisthostromes that can justify a syn-sedimentary tectonic activity. Martín-Martín et al. [20] studied the Miocene evolution of the same area, and by means of a better chronostratigraphic resolution, proposed a more advanced reconstruction of the stratigraphic architecture. These studies detected the presence of two main depositional sequences (Upper Burdigalian-Upper Serravallian and Upper-Middle Tortonian in age) in the Pila and Carche Cenozoic basins. According to the lateral-vertical distribution of the lithofacies and the thicknesses of the stratigraphic formations, the migration of the foredeep has been better specified, highlighting a complex tectono-sedimentary evolution. The same authors (Martín-Martín et al. [21,22]) studying the Cenozoic basins in the Alicante province recognized that the Miocene-Quaternary shallow marine and continental infilling has been controlled by the evolution of several curvilinear faults involving salt tectonics. These authors also specified that the occurrence of Triassic shales and evaporites played a fundamental role in the tectonic evolution of the study area since the salt material flowed along faults, generating salt walls in root zones and salt push-up structures at the surface.

In conclusion, the extensive information from the numerous previous studies, if taken as a whole, and analyzed and correlated, allow for synthesizing the tectono-sedimentary evolution of the Cenozoic basins of the eastern EBZ, evidencing its character of a key area.

\section{Geological Setting}

The Mesozoic of the EBZ is classically subdivided into the following domains: (1) the Prebetic Domain, which represents the Jurassic platform realm, having stratigraphic continuity with the foreland (Iberian Massif), and (2) the southern and southeastern Subbetic Domain, representing a Jurassic deeper-water area subdivided into several sub-Domains (i.e., Internal, Median and External sub-Domains). Both domains are characterized by Triassic to Cenozoic deposits, progressively deformed from south to north with development of fold and nappes during the Middle-Late Miocene [16]. The presence of major unconformities led Vera [17] to define the occurrence of VIII Main Sedimentary Cycles in the EBZ (Figure 2).

The EBZ in the Murcia sector consists of SW-NE aligned structural highs (folds and thrusts), that separate irregular depressions, usually narrow strips (corridors), which during the Cenozoic, represented basinal areas (Figure 2).

Differently, the EBZ of the Alicante sector is characterized by a net of strike-slip fault systems (Figure 3) roughly oriented as follows: N70E (Cadiz-Alicante Accident system), N155E and N120E. These faults, which were active from the Early-Middle Miocene onwards [21,22], are recognizable nowadays through the presence of outcrops of Triassic clays with gypsum. Neogene deposits also appear associated to subsiding areas linked to the strike-slip faulting $[23,24]$. Moreover, blocks with folded Mesozoic rocks are present. This structural system is related to a transpressive tectonic regime in the context of a compressive tectonics regional framework, established from the Middle Miocene onwards [21,22]. Nevertheless, the Cenozoic basins are now fragmented again into several blocks limited by main dextral faults (Figure 3).

\section{Stratigraphic Framework}

Previous studies on Cenozoic basins of the eastern EBZ [15,18-22] reconstructed a detailed stratigraphic framework of the Pila-Carche, Campello and Agost Cenozoic basins in the Murcia 
(Figure 2) and Alicante (Figure 3) provinces. On the basis of these previous works, the reconstructed geological history allows for considering these basins as key areas, well representative of the Cenozoic evolutionary stratigraphic framework. The resulting data and the recognized main tectonic events can be extended to other areas of the eastern EBZ. The stratigraphy is shown in Figures 4-7 and the description is synthesized in the following lines.

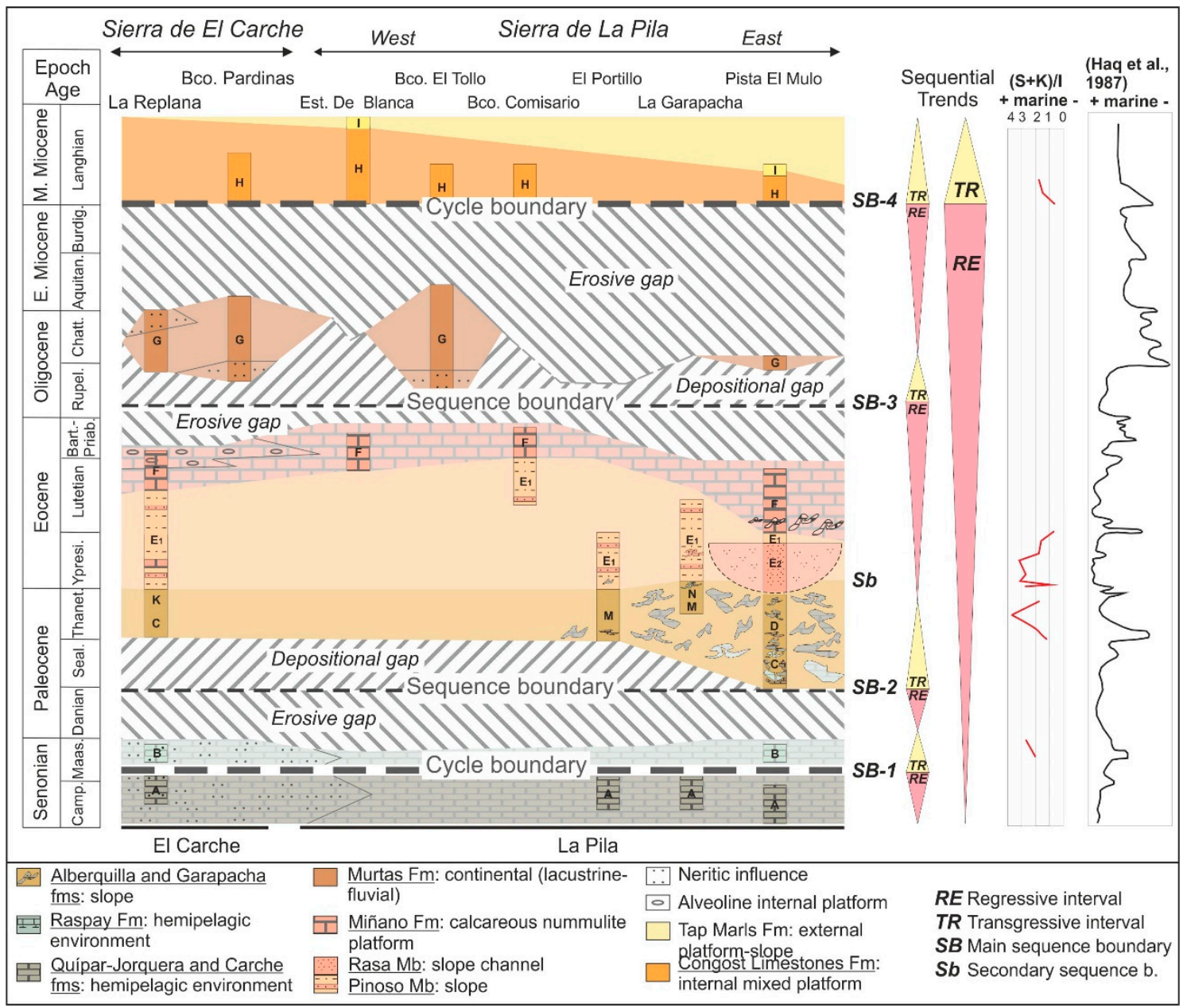

Figure 4. Stratigraphic framework and regional correlation of the Paleogene-Aquitanian sedimentary suite in the Pila-Carche Basin (Murcia sector) of the eastern EBZ (after Reference [19]; modified). Two sections are presented in the Sierra de El Carche (La Replana and Barranco Pardinas) and six sections in the Sierra de la Pila (Estación de Blanca, Barranco de El Tollo, El Portillo, La Garrapacha and Pista del Mulo). In the correlation, the main and secondary sequence boundaries ( $\mathrm{SB}, \mathrm{Sb}$, respectively) are shown. Also, the erosive and depositional gaps are mentioned. In the right part of the figure, the transgressive (TR) or regressive (RE) trending are marked, and also, the correlation with the standard eustatic curve. 


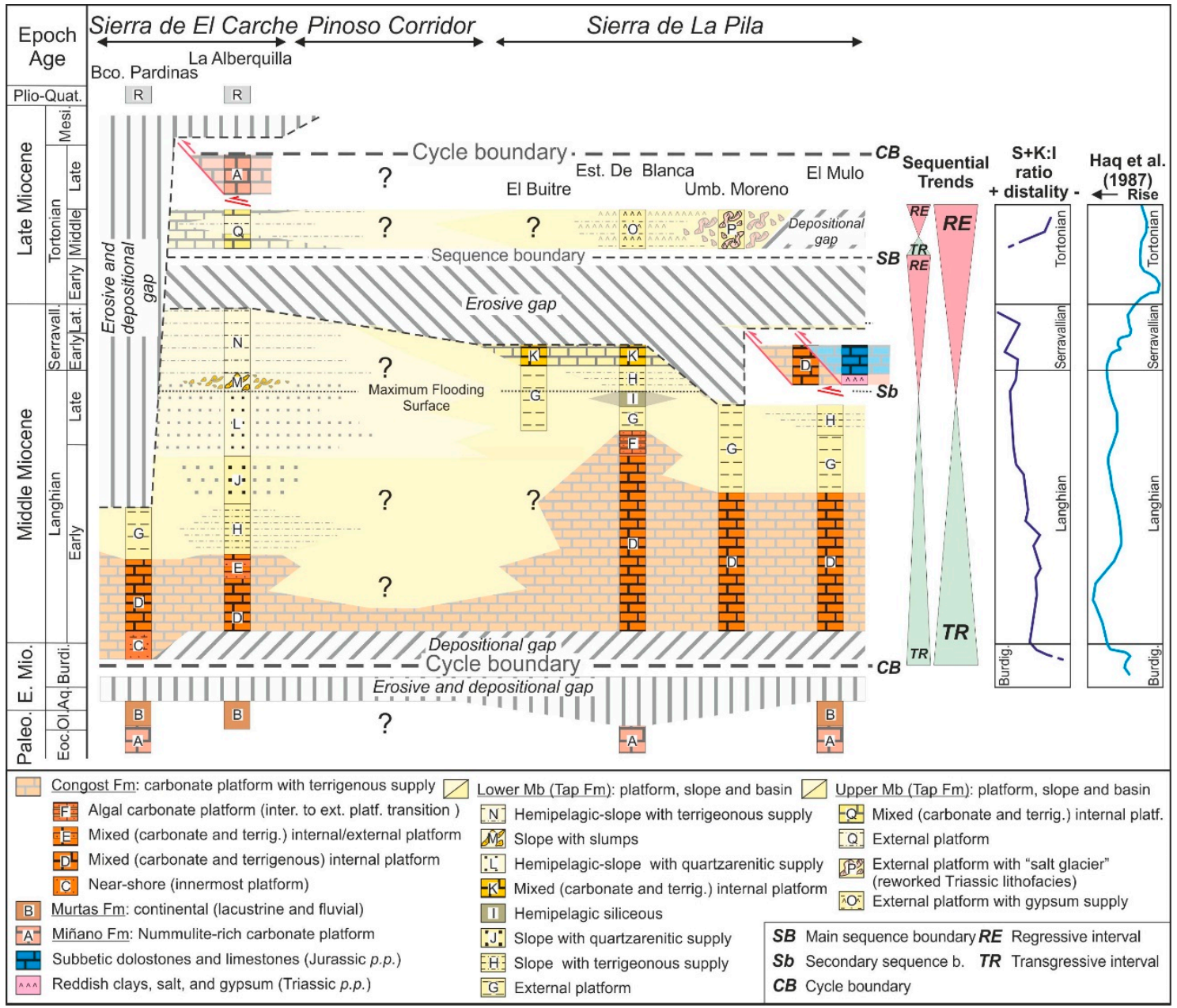

Figure 5. Stratigraphy and lateral correlation of the Neogene succession of the Pila-Carche Basin (Murcia sector) in the eastern EBZ (after Reference [20]; modified). Two stratigraphic sections have been reconstructed in the Sierra de El Carche (Barranco Pardinas and Alberquilla) and four in the Sierra de la Pila (El Buitre, Estación de Blanca, Umbría de Moreno and Pista del Mulo). The correlation highlighted main and secondary sequence boundaries ( $\mathrm{SB}, \mathrm{Sb}$, respectively). The erosive and depositional gaps are also detected together with the transgressive (TR) and regressive (RE) trend (separated by a maximum flooding surface). A correlation with the standard eustatic curve is also shown in the right side of the figure. 


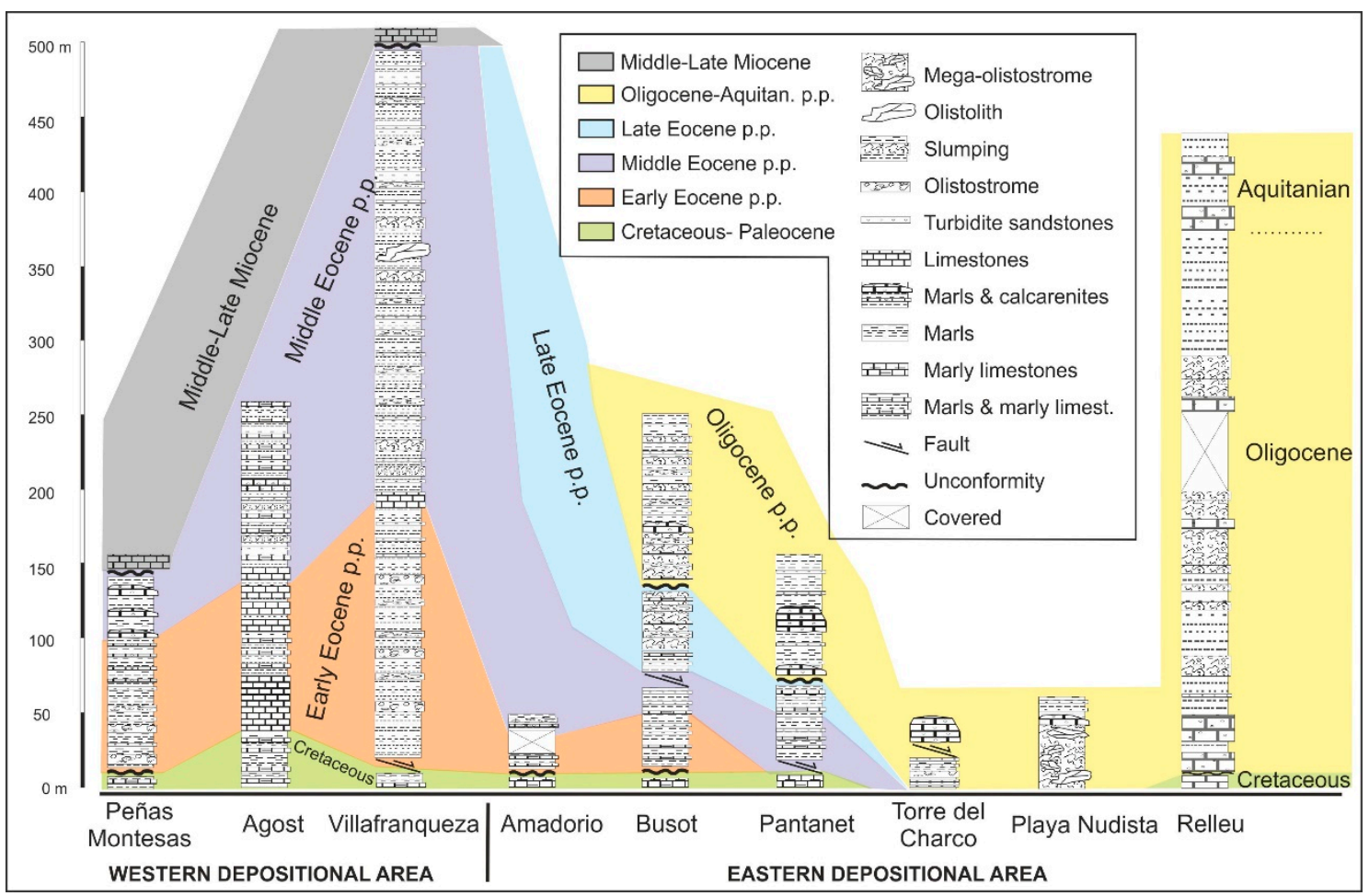

Figure 6. Stratigraphic columns and correlation of Paleogene-Aquitanian sediments of the Cenozoic Alicante Trough (Alicante sector) in the eastern EBZ (after References [15,18]; modified). Three stratigraphic sections are representative for the Western Depositional Area of the Alicante Trough (Peñas Montesas, Agost and Villafranqueza) and six stratigraphic sections for the Eastern Depositional Area of the same trough (Amadorio, Busot, Pantanet, Torre del Charco, Playa Nudista and Relleu). 


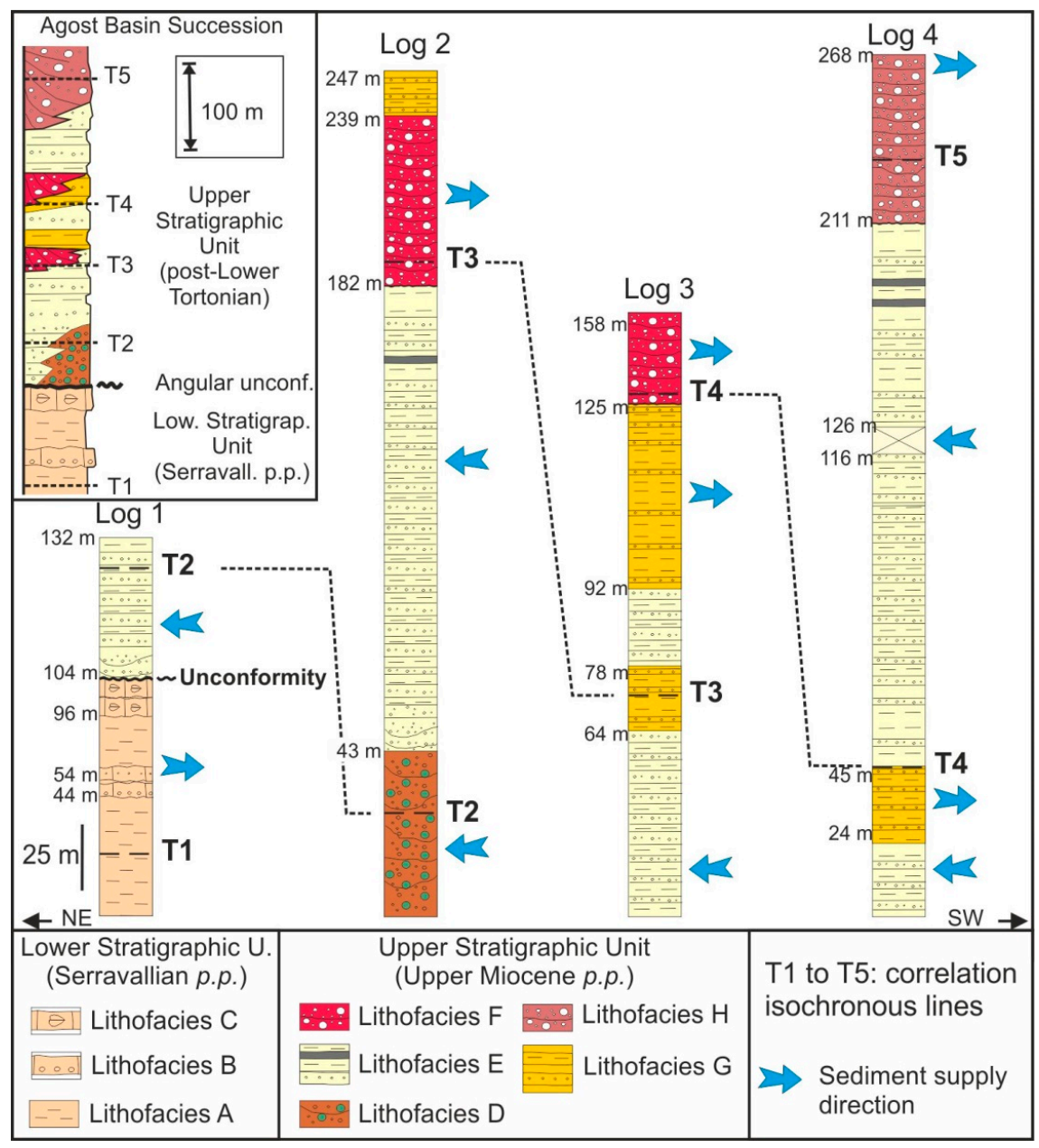

Figure 7. Stratigraphic columns of the Neogene stratigraphic units of the Agost Basin (Alicante province) of the eastern EBZ (after Reference [22]; modified). Four stratigraphic sections are presented to characterize the succession of the Agost Basin. Two stratigraphic units (Serravallian p.p. and Upper Miocene p.p. in age, respectively) were identified. Five isochronous lines are used for correlation deduced from the geological map. The direction of the sediment supply is indicated by the blue arrows, while a synthetic column is presented in the upper left corner.

\subsection{Murcia Sector (Cenozoic Pila-Carche Basin)}

The Upper Cretaceous stratigraphic succession (Figure 4) is represented by the following formations (Fm): El Charche Fm and Quípar-Jorquera Fm (Lithofacies A: Figure 4), which are made of limestones, marly limestones and thin beds of sandy marls (neritic to pelagic environment), and Raspay Fm (Lithofacies B: Figure 4), which is made up of sandy marls and thin beds of marly limestones of hemipelagic environment. A minor paraconformity between this last formation and the underlying succession was detected by means of biostratigraphic analysis with planktonic foraminifera.

Lithofacies C, D, K, N and M (Figure 4), corresponding to the Alberquilla and Garapacha fms (Paleocene to Lower Ypresian), deposited above a main angular unconformity well controlled in the field and with a gap affecting the Lower-Middle Paleocene, and checked in most of the examined sections. These units are characterized by limestones, microcodites and marls with the presence of slumps and olistostromes coming from a carbonate platform and deposited on the slope.

The Pinoso-Rasa Fm (Lower Ypresian-Upper Lutetian, defined as Lithofacies E, Figure 4) has been recognized subdivided into two stratigraphic members (E1 and E2), and deposited above a minor unconformity. This formation consists mainly of pelites, and channelized turbidite arenites, indicating a probable slope environment. 
The Miñano Limestones Fm (Lithofacies F and J: Figure 4), which is represented by nummulite-alveoline limestones (Middle-Upper Eocene), appears after a gradual transition. This unit indicates an internal carbonate platform sometimes affected by tectonic instability, resulting in the presence of syn-sedimentary folds.

The top of the Paleogene sedimentation corresponds with the Murtas Fm (Lithofacies G: Figure 4), which deposited above a main angular unconformity. This unit probably represents a transition from a marshy/beach/lagoon environment (yellowish marls and sands) to fluvial (continental red beds with conglomerates, sands, silts and clays) and lacustrine (whitish gastropod limestones) continental environments (Oligocene to Early Aquitanian). This formation clearly lies unconformably above the underlying formations, which are topped by an unconformity with a paleokarst surface well-recognized in several outcrops.

The Miocene succession of the Pila-Carche Basin is represented by the Upper Burdigalian to Lower Langhian Congost Fm, and the Lower and Upper members of Tap Fm (Figure 5). The Congost Fm unconformably (angular unconformity) overlies the Miñano and Murtas Fms and is subdivided into four lithofacies (C to F: Figure 5), which are made up of a great variety of shallow-water marine deposits: calcarenites with thick beach laminations, marine platform biocalcarenites and marls and marls with biocalcarenites and recifal biostromes of external platform-upper slope.

The formation gradually passes to the Lower member of the Tap Fm (Upper Langhian-Upper Serravallian), which is characterized by eight lithofacies ((G to K) Figure 5). In fact, the unit displays these lithofacies: external platform algal biocalcarenites with marly intercalations, external platform to upper slope sandy marls and biocalcarenites, probably slope-related marls with intercalations of turbidite arenites, slumps and olisthostromes, and deep basin siliceous and diatomaceous marls.

The Upper member of the Tap Fm (Middle Tortonian) lies above another paraconformity corresponding to a time gap of $3 \mathrm{Ma}$. This member is characterized by four lithofacies (O to R: Figure 5) formed by deposits belonging to different realms, from deep- to shallow-water marine environments: reworked Triassic included in olisthostromic deposits (slope), calcarenites (internal platform), diatomaceous silty sands and mudstones with diatomites (external platform). This unit is unconformably (angular unconformity) covered by the Pliocene-Quaternary succession (Lithofacies S, Figure 5).

\subsection{Alicante Sector (Cenozoic Alicante Trough and Agost Basin)}

Also, in this sector, the main unconformities observed in the previous sectors were recognized, but with some important differences. The Paleogene-Aquitanian succession (Figure 6) studied in the Alicante Trough $[15,18]$ allowed to define only informal stratigraphic units referable to the Eocene p.p. and Oligo-Aquitanian p.p.

The first difference with respect to the Murcia sector consists in the absence of the Paleocene deposits (Alberquilla and Garapacha fms) and in the fact that the lower main unconformity is present at the base of the Eocene. The Eocene deposits are referable to an external platform environment located in the western part of the trough, and to a slope to deep basin in the eastern one. Furthermore, they can be correlated with the lithofacies of the Pila-Rasa Fm of the Murcia sector. Turbiditic arenites, slumps and olisthostromes are also well exposed in the eastern portion of the Alicante Trough.

Another difference with respect to the Murcia sector is that the Upper Eocene deposits developed on the slope of a deep basin and are not related to a platform, as in the case of the Miñano Fm. The platforms are located northward, in continuity with the Iberian Massif [12-14] and since the turbidite deposits contain clasts of nummulites, these platforms constitute the most probable source areas for the Alicante Trough.

After the second main unconformity, the Oligocene-Aquitanian succession is well represented, but in this sector, it indicates an external platform to slope marine environment; this is in contrast to the Murcia sector, where the corresponding deposits (Murtas Fm) are of continental environment. The main lithofacies are represented by turbidite arenites, olisthostromes, slumps and pillow-beds, 
which are indicative of syn-sedimentary tectonic activity in the southern and south-eastern source areas [18].

The Burdigalian-Langhian Congost Fm and the Lower member (Upper Langhian-Upper Serravallian) and Upper member (Middle Tortonian) of the Tap Fm have not been recognized in the Alicante Trough. Instead, the two members of the Tap Fm are represented in the Agost Basin, where they correspond to four representative stratigraphic successions (Figure 7) [21,22]. In this case, the whole succession was subdivided into two main stratigraphic units separated by an angular unconformity (corresponding to the previously mentioned fourth main unconformity recognized in the area), correlated with the Lower member and Upper member of the Tap Fm.

The Lower Stratigraphic Unit (Serravallian p.p.) consists of marine deposits (Figure 7), while the Upper Stratigraphic Unit (upper Miocene p.p.) is characterized by continental deposits (Figure 7). Both the units are contemporary to a strike-slip tectonics involving salt deposits. The overlying sub-horizontal Pliocene deposits seal the previous deposits and all tectonic structures by a major angular unconformity (Figure 7).

The Lower Stratigraphic Unit of the Agost Basin (Figure 7) is made up of three shallow marine lithofacies: (i) whitish marls and marly limestones (Lithofacies A, Figure 7), (ii) calcarenitic beds with conglomerate intercalations (Lithofacies B, Figure 7) and (iii) calcarenitic beds (Lithofacies C, Figure 7). This succession indicates a relative sea-level fall (from open- to shallow-water, with restricted marine conditions) and shows a typical regressive evolution. This local reconstruction corresponds to the evolutionary trend recognized at the regional scale [22], which is related to a progressive shallowing of the environment towards the northern Prebetic sub-Domain and a consequent deepening to the W-SW, where several structural highs and deep areas occur.

The Upper Stratigraphic Unit is more widespread and better preserved and is represented by five lithofacies (Figure 7). In more detail, in the lower part: (i) blocks, conglomerates, arenites and whitish clays and silts (Lithofacies D, Figure 7), which are referable to a continental foot-cliff depositional environment, (ii) whitish clays and silts with local black layers (lignite), arenites and channelized conglomerate intercalations (Lithofacies E, Figure 7), related to a fluvial and lacustrine realms, (iii) reddish conglomerates with blocks of Triassic gypsum (Lithofacies F, Figure 7), arranged in a fan shape depositional geometry and interpreted as a progradational deposition of alluvial fan in a fluvial to lacustrine environment, (iv) pinkish clays and silts with occasional arenites and conglomerate intercalations (Lithofacies G, Figure 7) arranged in a fan shape deposition of an alluvial realm and (v) progradational conglomerates with Cretaceous-Paleogene calcareous clasts and Triassic reddish clays (Lithofacies H, Figure 7), arranged in a fan structure sealing some faults. In summary, this unit is related to a fluvial and lacustrine depositional system in the central area of the basin, and to alluvial fans and cliff deposits in the basinal margins. Alluvial fan and cliff sediments were deposited in different margins of the basin according to the order of succession of faults' activation and development.

\section{Tectono-Sedimentary Evolution of the Cenozoic Basins of the Eastern External Betic Zone}

\subsection{The Murcia Sector (Cenozoic Pila-Carche Basin)}

In the Cenozoic successions of these basins, the recognition of unconformity boundaries allows for subdividing the sedimentary record into four tectono-stratigraphic successions characterized by a different temporal extension: (i) Upper Paleocene-Upper Eocene, (ii) Oligocene-Lower Aquitanian, (iii) Upper Burdigalian-Upper Serravallian and (iv) Upper Miocene p.p. (Figures 8 and 9). The whole stratigraphic record represents a geological cycle indicative of a regressive general trend and starting with a regressive phase (from hemipelagic to continental environments), then continuing with a second transgressive-regressive phase during the Middle to Late Miocene (Figures 8 and 9).

(i) The Upper Paleocene-Upper Eocene tectono-stratigraphic unit (Figure 8) shows, after an initial transgression, a progressive shallowing upward marine trend. During the Paleocene to Early Eocene, the sedimentation (Alberquilla, Garapacha, Pinoso-Rasa fms) reflects a slope environment 
that evolved during the Middle-Late Eocene to a carbonate platform environment (Miñano Fm). A main unconformity boundary in the Early Oligocene marks a stratigraphic gap also evidenced by a widespread paleokarst, pointing out an emersion of the basin.

(ii) During the Oligocene (Murtas Fm), a transgression occurred with the development of marshy and beach lithofacies (Figure 8), followed by a new regressive depositional trend indicated by continental lacustrine and fluvial deposits during most of the Oligocene up to the Aquitanian.
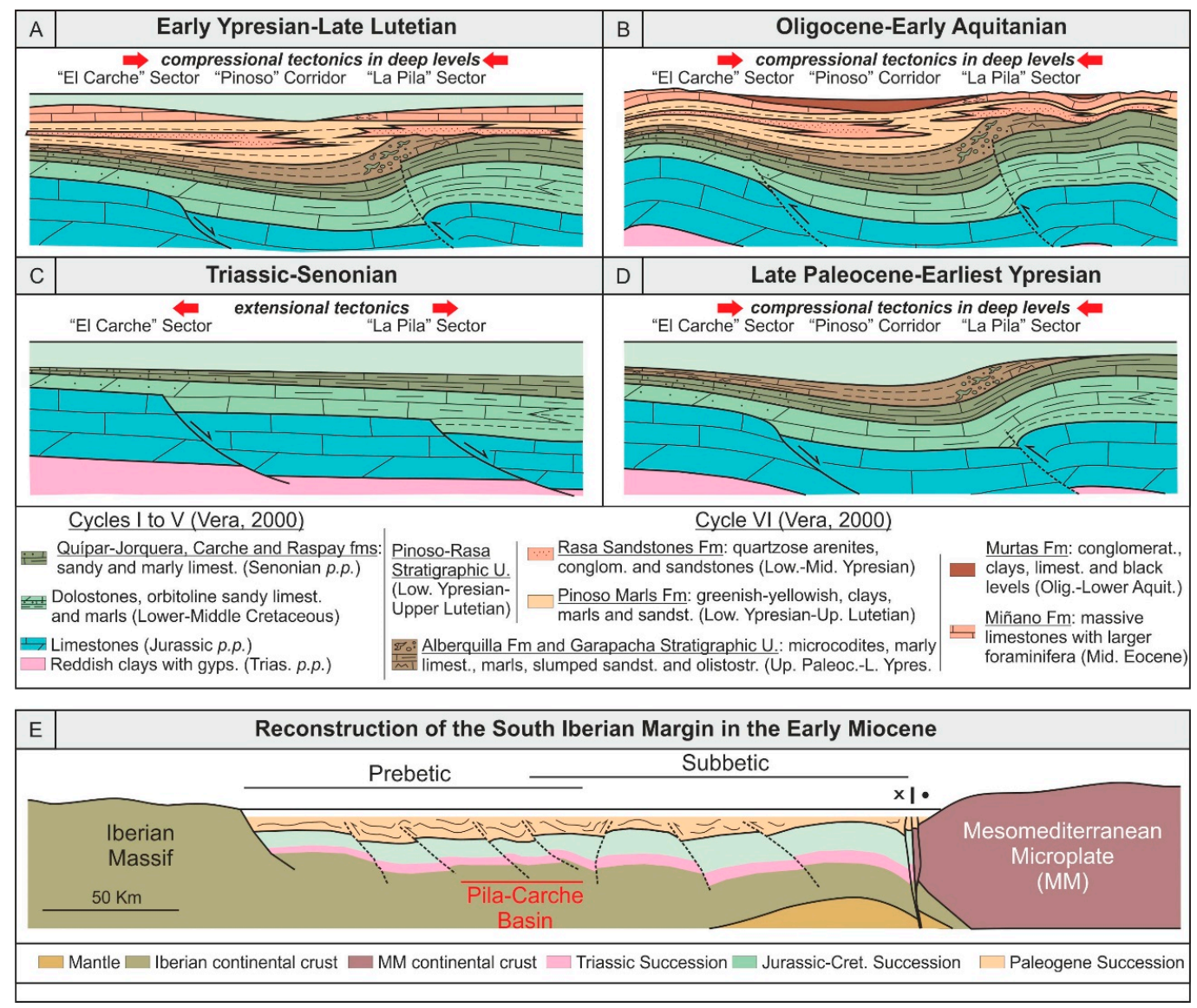

Figure 8. Paleogene tectono-sedimentary evolution of the Pila-Carche Cenozoic Basin (Murcia sector) of the eastern EBZ (after Reference [19]; modified). (A) Paleogeographic sketch showing a cross-section referable to the Late Ypressian-Early Lutetian interval, (B) paleogeographic sketch showing a cross-section referable to the Oligocene-Early Aquitanian interval, (C) paleogeographic sketch showing a cross-section referable to the Triassic-Senonian interval, (D) paleogeographic sketch showing a cross-section referable to the Late Paleocene-Earliest Ypressian interval, (E) paleogeographic sketch showing a cross-section referable to the Early Miocene.

Thickness and areal distribution of lithofacies of this tectono-stratigraphic unit indicate a subsidence area located between other uplifting ones (Figure 8). During the Paleogene-Aquitanian, the tectonic framework was characterized by a blind tectonics for the reactivation of old faults and the presence of Jurassic-Cretaceous blocks affected by folding in deep levels. These tectonics caused differential vertical movements generating areas affected by subsidence and other uplifting areas. The thick marine and transitional environment sedimentation is usually followed by continental deposits formed in a condition of relative subsidence. Instead, the uplifted areas are highlighted by paleokarst surfaces and a thin continental cover.

(iii) The Upper Burdigalian-Upper Serravallian tectono-stratigraphic unit (Pila-Carche Basin, Figure 9) shows a transgressive-regressive trend. The transgression, which began in the Late Burdigalian, 
reaching the Late Langhian (Congost Fm), results younger in some sectors of the basins because of the onlap arrangement of transgressive deposits on the previous deformed succession. The evolution begins with an internal platform environment sedimentation, while during the Early Langhian, a mixed carbonate and terrigenous supply indicates an external platform to upper slope environment.

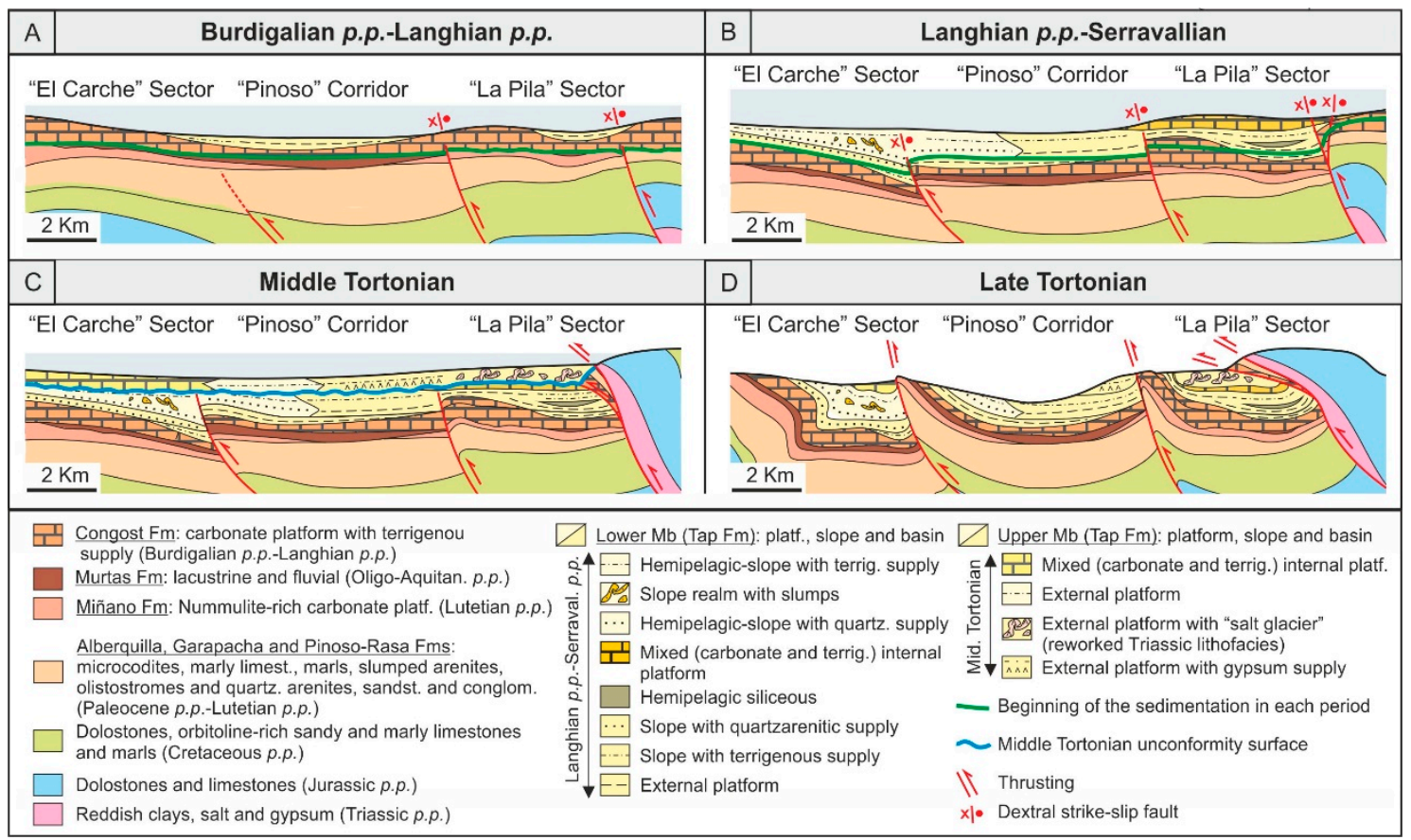

Figure 9. Neogene tectono-sedimentary evolution of the Cenozoic Pila-Carche Basin (Murcia sector) in the eastern EBZ (after Reference [20]; modified). (A) Paleogeographic sketch showing a cross-section referable to the Burdigalian-Langhian p.p. interval, (B) paleogeographic sketch showing a cross-section referable to the Langhian p.p.-Serravallian interval, (C) paleogeographic sketch showing a cross-section referable to the Middle Tortonian, (D) paleogeographic sketch showing a cross-section referable to the Late Tortonian.

Later, the Burdigalian upper Langhian Congost Fm passes laterally and upwards to the Lower member of the Tap Fm (Figure 9), and the presence of clastic deposits suggests a transition platform, slope and basinal environments, with an increase of terrigenous inputs. The Lower member of the Tap Fm is characterized by deeper marine lithofacies, showing a quartzarenitic supply. The deepest environment is also marked by Upper Langhian p.p. silexites. In turn, the presence of slumps implies the presence of a slope. Both silexites and slumps are considered to indicate a deepening phase occurring during Miocene. Compression, folding and lithostatic load related to the overlapping nappes resulted in the development of subsidence or uplifting areas, as shown by the increasing thicknesses of the Langhian-Serravallian successions.

The fourth main unconformity is probably related to a new emersion at the beginning of the compressional thin-skinned tectonics and recorded by a marked stratigraphic gap (early Tortonian).

(iv) The Middle Tortonian tectono-stratigraphic unit (Pila-Carche Basin) shows a new transgressive-regressive cycle (Upper member of the Tap Fm). According to the sedimentological data, the depositional environment of this unit ranges between internal mixed (carbonate and siliciclastic) platform to external platform. Reworked Triassic clays and gypsum (olisthostromes) indicate a deposition on a slope realm. In this phase, the faulting reached the surface, generating thrusts and strike-slip faults and related features. The blocks between the faults were also folded and sometimes developed to form nappes. 


\subsection{Alicante Sector (Cenozoic Alicante Trough and Agost Basin)}

The Paleogene deposition of the Alicante Trough shows a clear regressive trend from a slope environment (Eocene) to a shelf environment (Oligocene-Aquitanian), accompanied by an increase of tectofacies upwards. During the Eocene, turbidite arenites and slumps coming from the western-northwestern area and showing a transgressive trend, deposited. Oligocene-Lower Aquitanian slumps, olisthostromes, mega-olisthostromes and pillow-beds (coming from the eastern-southeastern area) are instead arranged to show a regressive-transgressive-regressive trend.

During the Paleogene, the Alicante Trough (Figure 10) is a subsidence area bounded by two northwestern and southeastern margins related to the Prebetic Zone and External Subbetic subdomain, respectively [15].

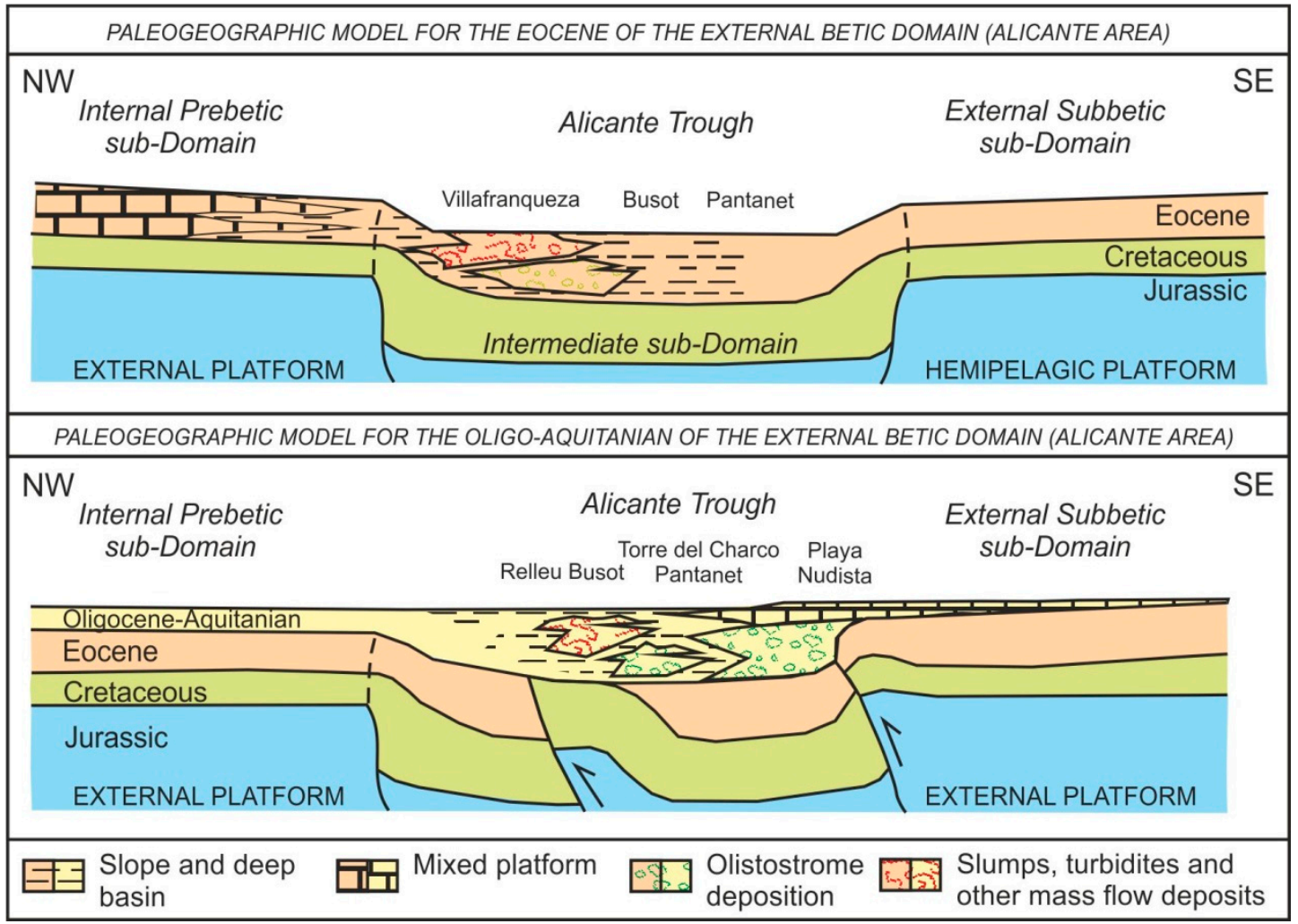

Figure 10. Eocene and Oligo-Aquitanian tectono-sedimentary evolution of the Cenozoic Alicante Trough and neighbor areas (Alicante province) of the eastern EBZ (after Reference [18]; modified). Paleogeographic sketch showing a cross-section referable to the Oligo-Aquitanian interval, in the lower part, and to the Eocene, in the upper part.

During the Eocene (Figure 10), the sedimentation of this trough was mainly influenced by the western or northwestern Prebetic margin, by an incipient tectonic instability that gave rise to turbidites associated with hemipelagic deposits, arranged in triplet para-sequences. This Eocene sedimentation is correlated with the Pila-Rasa Fm (Murcia sector). In contrast, during the Oligocene and up to Early Aquitanian (Figure 10), the basin was mainly influenced by the opposite margin, located southeastwards (Subbetic substratum). In this case, the sedimentation is related to marine realms, differently with respect to the continental environments of the Murtas Fm (Murcia sector). The lithofacies association (marls with slumps, olistostromes, mega-olistostromes and pillow-beds) indicates the dismantling of a platform, also by means of paleocurrents, and the west- or northwestwards-facing of slumps, from which a tectonic activity of the margin is deduced. Pillow-beds, which are structures interpreted as seismites as a result of high-magnitude earthquakes [11], favored the construction of submarine fan systems. 
During the Miocene, the Congost Fm is not represented but the Tap Fm is recognizable in the Alicante sector. In any case, the Cenozoic basins evolved in a different way in the Alicante region (Agost Basin, Figure 11). In this region, fault bends acted as transtensive dextral strike-slip systems delimiting pull-apart-like basins with shallow marine and continental deposits. The reorientation of the main regional stress caused changes in the kinematics of the strike-slip faults, which evolved as reverse (compressive) faults at first, and as sinistral (transpressive) faults later (Figure 10). During the transtensive phase, the Triassic salt risen from a deep stratigraphic level tended to escape to the surface as salt walls to be eroded and deposited as alluvial fan in the basins. The deposition of the alluvial fans changed its position over time, with these depositional systems being progressively replaced by others according to the displacement of the active faults.
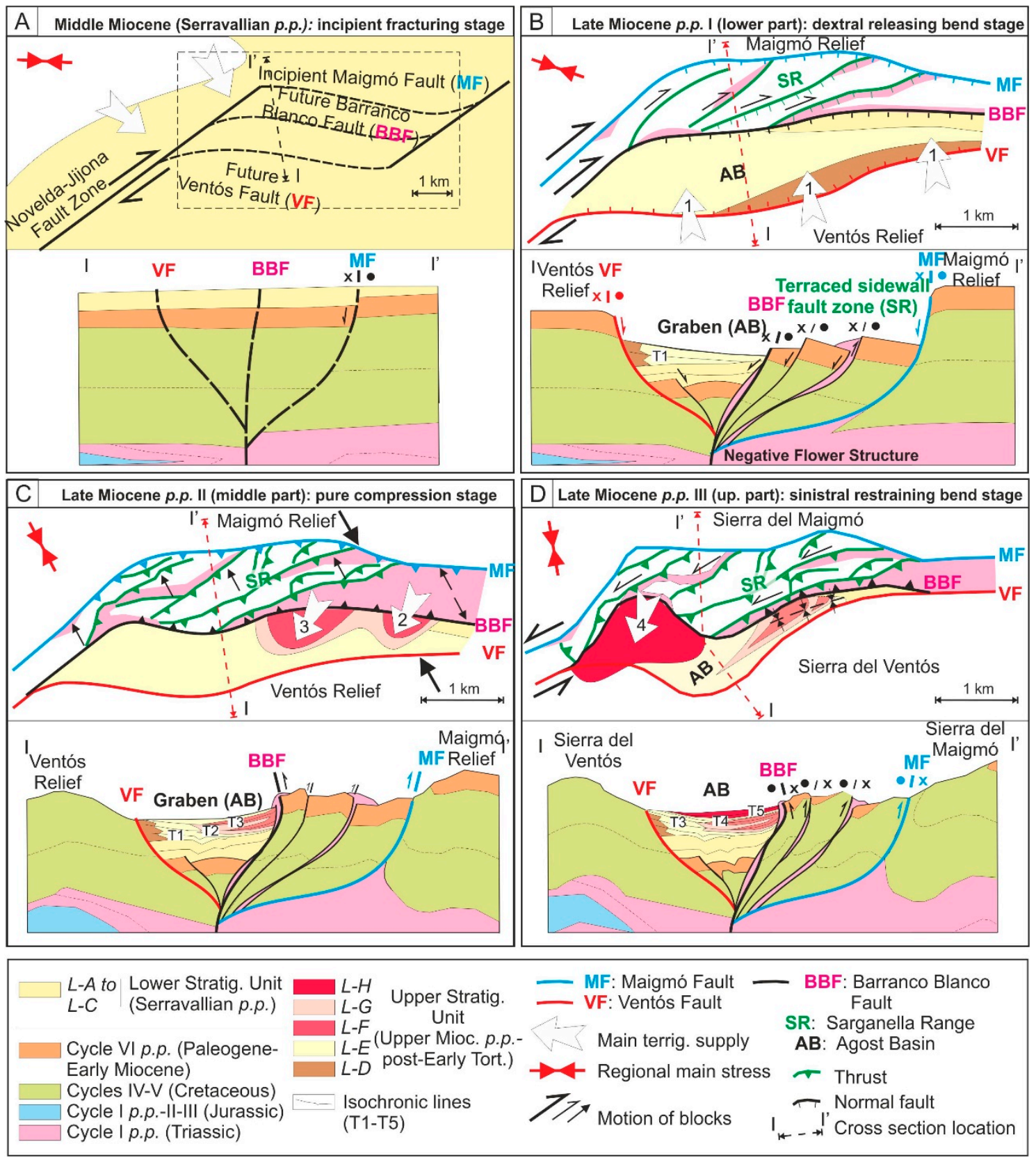

Figure 11. Neogene tectono-sedimentary evolution of the Agost Basin (Alicante province) of the eastern EBZ (after Reference [21]; modified). The main regional stress, motion of blocks, faults' actuation and main terrigenous supply is represented. (A) paleogeographic sketch map and section of the Serravallian, (B,C,D) paleogeographic sketch maps and sections of the Late Miocene. 


\section{Discussion and Conclusions}

The Cenozoic basins of the eastern EBZ were located over a Mesozoic sedimentary substratum after the tectonic inversion (from extensional to compressional) occurring at the latest Cretaceous [15,18]. These basins were subsidence areas nourished by located nearby structural heights. Some differences in the sedimentary record observed in these basins can be summarized as follows: (1) The Paleocene deposits are not present in the Alicante sector where they are replaced by a marked unconformity, located at the base of the Eocene; in the Murcia sector, the gravitational slope environment related to the Paleocene deposits are well represented. (2) The deeper Eocene deposits recognized in the Alicante sector (external platform, slope and deep basin environment) are in contrast with the Middle-Upper Eocene shallow-water marine ones (internal platform) of the Murcia sector. (3) The Oligocene-Aquitanian deposits are related to a continental environment and are very reduced in the Murcia sector, while they are well represented in the Alicante sector where they indicate an initial marine external platform environment, which passes to a slope environment.

In both areas, terrigenous supplies have been supplied from the active basinal margins, in the Early Paleogene from the northwestern area and in the Late Paleogene-Aquitanian from the southeastern area. In these successions, turbidites, olistostromes, slumps and pillow-beds have been interpreted as indicative of an early tectonic activity (Guerrera and Martín-Martín [18]). A progressive eastward reduction of subdomain areas in the EBZ has been interpreted as due to the action of the Cadiz-Alicante strike-slip fault zone [35] from the Lower-Middle Miocene onwards. Nevertheless, according to Guerrera et al. [15] and Guerrera and Martín-Martín [18], this progressive sub-domain's reduction should be older and related to the transform fault responsible for the Internal-External Zone Boundary tectonic contact (References [1,5,6], and references therein), which is related to the collision between the Mesomediterranean Microplate (MM) and the EBZ (Figure 12A). In our opinion, the early and local tectonic activity recorded in the eastern EBZ is probably due to the paleogeographic position of the eastern EBZ located very close to the IBZ during this period. This activity could explain the dismantling of the External Subbetics during the Oligocene-Early Aquitanian, since this sub-Domain was the most internal Subbetic one, located close to the MM and separated with respect to the latter by the mentioned active transform fault.

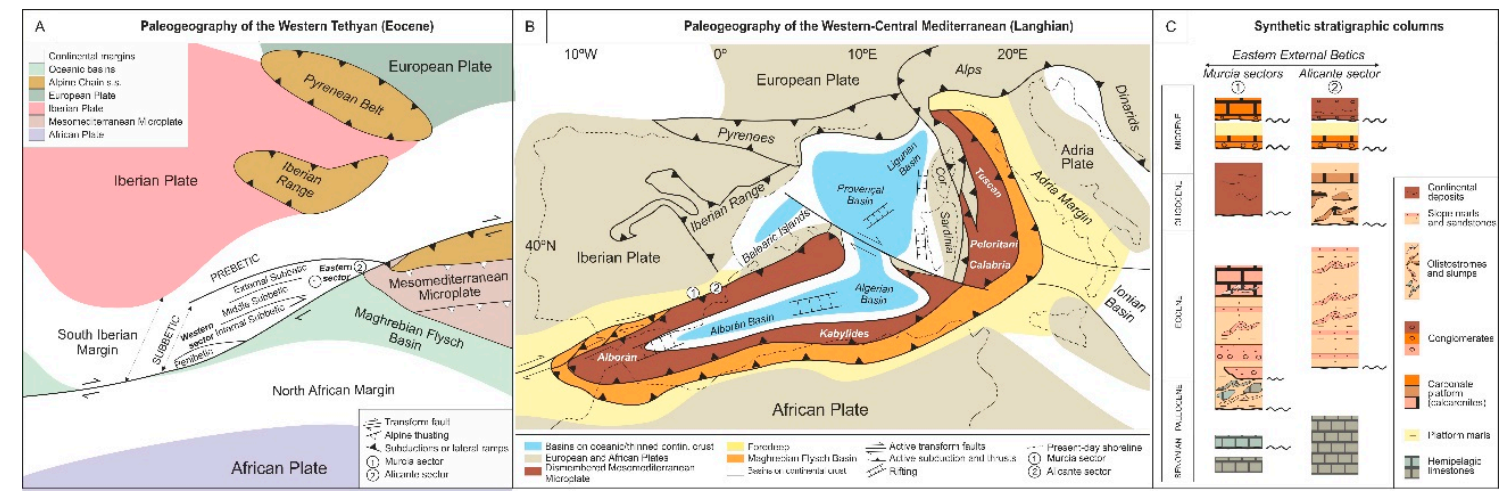

Figure 12. General geodynamic framework of the eastern EBZ in the context of the western peri-Mediterranean alpine chains. (A) geodynamic interpretation of the western Tethys during the Eocene (after Reference [19], modified), (B) geodynamic framework of the central-western Mediterranean area during the Miocene (modified from Reference [20]), (C) synthetic columns of the Cenozoic Bains in the Murcia and Alicante sectors of the eastern EBZ (after Guerrera et al. [19], modified)

The Miocene deposits (Congost and Tap fms) are absent in the Alicante Trough but the Lower and Upper Members of the Tap Fm are recognizable in the Agost Basin [21,22]. During the Middle Miocene, the EBZ was affected by a net of strike-slip fault-related bend zones experiencing kinematic changes over time from a transtensive dextral to a transpressive sinistral one, according to the main regional 
stress. Subsidence areas delimited by fault traces and folded structural highs were also developed and the fault traces, usually present as Triassic salty materials, were injected. During the Late Miocene, this salty material was eroded and redeposited during the construction of the alluvial fans, which occurs in relation to and under the control of the strike-slip fault zones movement. This tectonic activity, and related bends of strike-slip faults, should be connected with the regional framework characterized by the Mediterranean opening (Figure 12B) and the westward migration of the Internal Betic Zone (the previous MM) by means of a transform fault.

In the sedimentary record of the Cenozoic basins (eastern EBZ), the following four main unconformities are recognizable (Figure 12C): (1) at the Cretaceous-Paleogene boundary (angular unconformity), recorded at the K/Paleocene boundary (with a related Danian gap) in the Murcia sector, and at the $\mathrm{K} /$ Eocene boundary (with a gap covering the entire Paleocene) in the Alicante sector, (2) at the Eocene-Oligocene boundary (with an angular unconformity, a paleokarst surface and a stratigraphic gap corresponding to the Bartonian-Priabonian and the Rupelian p.p.). This unconformity is quite synchronous in the whole area. (3) In the Burdigalian (with an angular unconformity and a stratigraphic gap corresponding to the Late Aquitanian-Early Burdigalian), this unconformity is also quite synchronous, and (4) in the Late Miocene (Lower/Middle Tortonian) and recorded in the whole eastern EBZ as a paraconformity with a gap affecting the Serravallian p.p. and the Early Tortonian.

The detected unconformities delimitate the following depositional sequences: (1) the Paleocene p.p.-Late Eocene p.p., showing a transgressive-regressive trend with a maximum flooding surface at the Paleocene/Eocene boundary, (2) the Oligocene p.p.-Aquitanian p.p., showing a transgressive-regressive trend but with a too-reduced sedimentation to deduce anything more, (3) the Burdigalian p.p.-Serravallian p.p., showing a transgressive-regressive trend with a maximum flooding surface at the latest Langhian and (4) the Middle Tortonian p.p., showing a transgressive-regressive trend but with a too-reduced sedimentation to deduce anything more.

The comparison among unconformities and trend evolution of the depositional sequences with the standard eustatic curves (Figures 4 and 5) allow some important constraints: (1) the Paleocene transgression corresponds with an eustatic lowering (Figure 4) because the evolution should be tectonically controlled, (2) the Eocene/Oligocene boundary unconformity is well correlated with an eustatic lowering (Figure 4) and the Oligocene-Aquitanian depositional sequence can be explained as caused by an eustatic phenomenon, (3) the Langhian transgressive trend corresponds with several transgressive-regressive variations in the eustatic curve (Figure 5), so that it should be controlled by tectonics and (4) the transgressive-regressive trend of the Middle Tortonian p.p. depositional sequence corresponds with a stand in the eustatic curve (Figure 5) that should be explained by tectonics.

In short, depositional sequences and unconformities partially match with the sedimentary cycles and cycle boundaries of the EBZ proposed by Vera [16,17]. So, the K/T unconformity marks the beginning of the Cycle VI and the intra-Burdigalian boundary unconformity indicates the beginning of the Cycle VII. Nevertheless, two new unconformities have been described before dividing in turn the Cycles VI (at the Eocene/Oligocene boundary) and VII (Lower/Middle Tortonian). These two new unconformities add more detail to the reconstruction of the stratigraphic architecture of the Cenozoic basins of the EBZ.

Cenozoic basins started to develop over the Mesozoic basement after the first main unconformity. The Paleocene-Eocene slope and deep basin deposition is characterized by numerous sedimentary inputs consisting of turbidites, slumps, olisthostromes, mega-olistostromes and by pillow-beds, which point out early blind (deep-seated) tectonics acting mainly in the most internal subdomains of the EBZ and related to the geodynamic evolution of the western-most Tethys. The second unconformity leads to a shallowing during the Oligocene to Aquitanian marked by a shallow-water marine sedimentation in the Alicante sector, and even a continental deposition in the Murcia sector. In this latter period, tectonic conditions were similar to those of the previous period. Differently, the Miocene sedimentation was controlled by the development of superficial thrusts and/or bends on strike-slip faults, with all these structures being related to the geodynamic evolution linked to the Mediterranean opening. 
Thrusts and bends on strike-slip faults created subsidence areas (pull-apart basin-like), which created accommodation for successive sediments that deposited after the above-mentioned unconformity (3). Subsiding areas were bounded by structural highs affected by thrusts and folds. So, after the third unconformity, the sedimentation of these latest basins was mainly made by marine shallow-water to deep sediments (Lower member of Tap Fm) from Burdigalian to Serravallian. After the unconformity (4), during the Late Miocene (Tortonian), the bend development along strike-slip faults caused salt tectonic processes and the presence of shallow-water marine basins characterized by the Upper member of the Tap Fm (Murcia sector), or by continental (lacustrine and fluvial) deposition with alluvial fans in the Alicante sector. These alluvial fans were changing their position over time following the fault development, being mainly fed from fault-controlled rising of the Triassic material.

Author Contributions: All the authors (M.M.-M., F.G. and M.T.) contributed to the different parts of the article. All authors have read and agreed to the published version of the manuscript.

Funding: Research supported by: Research Project CGL2016-75679-P, Spanish Ministry of Education and Science; Research Groups, Projects of the Generalitat Valenciana, Alicante University (CTMA-IGA); University of Urbino Carlo Bo (funds to M.T.).

Acknowledgments: Authors wish to acknowledge two anonymous reviewers for useful comments and suggestions.

Conflicts of Interest: The authors declare no conflict of interest.

\section{References}

1. Guerrera, F.; Manuel Martiín-Martiín, M.; Mario Tramontana, M. Evolutionary geological models of the central-western peri-Mediterranean chains: A review. Int. Geol. Rev. 2019, 1706056. [CrossRef]

2. Martín-Martín, M.; Rey, J.; Alcalá-García, F.J.; Tosquella, J.; Deramond, J.; Lara-Corona, E.; Duranthon, F.; Antoine, P.O. Tectonic controls of the deposits of a foreland basin: An example from the Eocene Corbières-Minervois basin, France. Basin Res. 2001, 13, 419-433. [CrossRef]

3. Martín-Martín, M.; de Galdeano, C.S.; García-Tortosa, F.J.; Martín-Rojas, I. Tectonic units from the Sierra Espuña-Mula area (SE Spain): Implication on the triassic paleogeography and the geodynamic evolution for the betic-rif internal zone. Geodin. Acta 2006, 19, 1-9. [CrossRef]

4. Martín-Martín, M.; Martín-Rojas, I.; Caracuel, J.E.; Estévez-Rubio, A.; Martín-Algarra, A.; Sandoval, J. Tectonic framework and extensional pattern of the Malaguide Complex from Sierra Espuña (Internal Betiz Zone) during Jurassic-Cretaceous: Implications for the Westernmost Tethys geodynamic evolution. Int. J. Earth Sci. 2006, 95, 815-826. [CrossRef]

5. Martiín-Martiín, M.; Guerrera, F.; Tramontana, M. Geodynamic implications of the latest Chattian-Langhian central-western Mediterranean volcano-sedimentary event: A review. J. Geol. 2020, 128, 706262. [CrossRef]

6. Martiín-Martiín, M.; Guerrera, F.; Miclaus, C.; Tramontana, M. Similar Oligo-Miocene tectono-sedimen-tary evolution of the Paratethyan branches represented by the Moldavidian Basin and Maghrebian Flysch Basin. Sediment. Geol. 2020, 396, 105548. [CrossRef]

7. García-Hernández, M.; López-Garrido, A.C.; Rivas, P.; Sanz de Galdeano, C.; Vera, J.A. Mesozoic paleogeographic evolution of the External Zone of the Betic Cordillera. Geolgie Mijnb. 1980, 59, 155-168.

8. García-Dueñas, V. La Zona Subbética al N de Granada. Ph.D. Thesis, Universidad de Granada, Granada, Spain, January 1967; p. 417.

9. Vera, J.A. Estudio geológico de la zona Subbética en la transversal de Loja y sectores adyacentes. Mem. Del Inst. Geológico Y Min. España 1969, 72, 187.

10. Comas, M.C. Sobre la Geología de los Montes Orientales. Sedimentación y Evolución Paleogeográfica Desde el Jurásico al Mioceno Inferior (Zona Subbética. Andalucía). Ph.D. Thesis, Universidad De Bilbao, Bilbao, Spain, May 1978; p. 323.

11. Roep, T.B.; Everts, A.J. Pillow-beds: A new type of seismites? An example from an Oligocene turbidite fan complex, Alicante, Spain. Sedimentology 1992, 39, 711-724. [CrossRef]

12. Geel, T. Oligocene to early Miocene tectono-sedimentary history of the Alicante region (SE Spain): Implications for Western Mediterranean Evolution. Basin Res. 1995, 7, 313-336. [CrossRef] 
13. Geel, T. Recognition of stratigraphic sequences in carbonate platform and slope deposits: Empirical models based on microfacies analysis of Palaeogene deposists in southern Spain. Palaeogr. Palaeclimatol. Palaecol. 2000, 155, 211-238. [CrossRef]

14. Geel, T.; Roep, T.B.; Van Hinte, J.E.; Vail, P. Eocene Tectono-Sedimentary patterns in the Alicante Region (Southeastern Spain). Mesoz. Cenozoic Seq. Stratigr. Eur. Basins 1998, 60, 289-302.

15. Guerrera, F.; Estévez, A.; López-Arcos, M.; Martín-Martín, M.; Martín-Pérez, J.A.; Serrano, F. Paleogene tectono-sedimentary evolution of the Alicante trough (external Betic zone, SE Spain) and its bearing in the timing of deformation of the sud-Iberian Margin. Geodin. Acta Eur. J. Geodyn. 2006, 19, 87-101. [CrossRef]

16. Vera, J.A. El Terciario de la Cordillera Bética: Estado actual de conocimientos. Rev. Soc. Geológica España 2000, 12, 345-373.

17. Vera, J.A. Geología de España; IGME—Soc. Geológica España: Madrid, Spain, 2004; p. 884.

18. Guerrera, F.; Martín-Martín, M. Paleogene-Aquitanian tectonic breakup in the eastern External Betic Zone (Alicante, SE Spain). Rev. Soc. Geológica España 2014, 27, 271-285.

19. Guerrera, F.; Mancheño, M.A.; Martín-Martín, M.; Raffaelli, G.; Rodríguez-Estrella, T.; Serrano, F. Paleogene evolution of the External Betic Zone and geodynamic implications. Geol. Acta 2014, 12, 171-192.

20. Martín-Martín, M.; Guerrera, F.; Rodríguez-Estrella, T.; Serrano, F.; Alcalá, F.J.; Raffaelli, G.; Tramontana, M. Miocene tectono-sedimentary evolution of the eastern external Betic Cordillera (Spain). Geodin. Acta 2018, 30, 265-286. [CrossRef]

21. Martín-Martín, M.; Estévez, A.; Martín-Rojas, I.; Guerrera, F.; Alcalá, F.J.; Serrano, F.; Tramontana, M. The Agost Basin (Betic Cordillera, Alicante province, Spain): A pull-apart basin involving salt tectonics. Int. J. Earth Sci. 2018, 10, 655-671. [CrossRef]

22. Martín-Martín, M.; Guerrera, F.; Alcalá, F.J.; Serrano, F.; Tramontana, M. Source areas evolution in the Neogene Agost Basin (Betic Cordillera): Implications for regional reconstructions. Ital. J. Geosci. 2018, 137. [CrossRef]

23. Leret-Verdú, G.; Lendínez-González, A. Mapa Geológico de Elda Escala 1:50,000; No. 871. IGME-Soc.; Geológica España: Madrid, Spain, 1978.

24. De Ruig, M. Tectono-Sedimentary Evolution of the Prebetic Fold Belt of Alicante (SE Spain). Ph.D. Thesis, Vrije University Amsterdam, Amsterdam, The Netherlands, 1992; p. 207.

25. Botella y Hornos, F. Descripción Geológica y Minera de las Provincias de Murcia y Albacete; Imprenta del Colegio Nacional de Sordos y Ciegos: Madrid, Spain, 1868; p. 186.

26. Nicklés, R. Sur les terrains secondaires des provinces de Murcia, Almerie, Grenade et Alicante (Espagne). Comptes Rendus Geosci. 1896, 122, 550-553. (In French)

27. Azéma, J. Sur l'existence d'une zone intermédiaire entre Prébétique et Subbétique dans les provinces d'Alicante et de Murcie (Espagne). Comptes Rendus Geosci. 1966, 260, 4020-4023.

28. Azéma, J. Géologie des confins des provinces d'Alicante et de Murcia (Espagne). Bull. Soc. Géologique Fr. 1966, 8, 80-86. [CrossRef]

29. Azema, J. Étude géologique des Zones Externes des Cordillères Bétiques aux Confins des Provinces d'Alicante et de Murcia (Espagne). Ph.D. Thesis, Université Pierre et Marie Curie, París, France, 1977; p. 396.

30. Rodríguez-Estrella, T. Sintesis Geológica del Prebético de la Provincia de Alicante. I y II. Boletín Geológico y Minero de España; Instituto Geológico y Minero de España (IGME): Madrid, Spain, 1977; Volume LXXXVIII-III, pp. 183-214.

31. Rodríguez-Estrella, T. Geología e Hidrogeología del sEctor de Alcaraz-Liétor-Yeste (Provincia de Albacete); Síntesis Geológica de la Zona Prebética. Instituto Geológico y Minero de España (IGME): Madrid, Spain, 1979; Volume 278, p. 290.

32. Foucault, A. Découverte d'une nouvelle unité tectonique sous le massif subbetique de la Sierra Sagra (Andalousie). Comptes Rendus Geosci. 1960, 250, 20-38.

33. Montenat, C. Les Bassins Néogènes et Quaternaires du Levant d'Alicante à Murcia (Cordillères Bétiques Orientales, Espagne). Stratigraphie, Paléontologie et Evolution Dynamique; Laboratoire de Géologie de la Faculté des Sciences de l’Université de Lyon: Lyon, France, 1977; Volume 69, p. 345.

34. Seyfried, H. Der subbetische Jura von Murcia (Südost-Spanien). Geol. Jahrb. 1978, 29, 3-201.

35. Sanz de Galdeano, C. Los accidentes y fracturas principales de las Cordilleras Béticas. Estud. Geológicos 1983, 39, 157-167.

36. De Smet, M.E.M. Investigations of the Crevillente Fault Zone and Its Role in the Tectogenesis of the Betic Cordilleras, Southern Spain; Free University Press: Amsterdam, The Netherlands, 1984; p. 174. 
37. De Smet, M.E.M. Wrenching in the external zone of the Betic Cordilleras, southern Spain. Tectonophysics 1984, 107, 57-79. [CrossRef]

38. Del Olmo, W.M.; Leret Verdú, G.; Suárez Alba, J. La estructuración diapirica del Sector Prebético. Geogaceta 1986, 1, 43-44.

39. Alfaro, P. Neotectónica en la Cuenca del Bajo Segura. Ph. D. Thesis, Universidad de Alicante, Alicante, Spain, 1995; p. 217.

40. Chacón, B.; Martín-Chivelet, J. Subdivisión litoestratigráfica de las series hemipelágicas de edad Coniaciense-Thanetiense en el Prebético oriental (SE, España). Rev. Soc. Geológica España 2005, 18, 3-20.

(C) 2020 by the authors. Licensee MDPI, Basel, Switzerland. This article is an open access article distributed under the terms and conditions of the Creative Commons Attribution (CC BY) license (http://creativecommons.org/licenses/by/4.0/). 